\title{
Contrasting levels of polymorphism in cross-amplified microsatellites in two endangered xerothermophilous, obligatorily myrmecophilous, butterflies of the genus Phengaris (Maculinea) (Lepidoptera: Lycaenidae)
}

\author{
Robert RUTKOWSKI ${ }^{1}$, Marcin SIELEZNIEW ${ }^{2}$ and AgNiESZKa SZOSTAK ${ }^{3}$ \\ ${ }^{1}$ Department of Molecular and Biometrical Techniques, Museum and Institute of Zoology, Polish Academy of Sciences, \\ Wilcza 64, PL-00-679 Warszawa, Poland; e-mail: robertrut@miiz.waw.pl \\ ${ }^{2}$ Department of Invertebrate Zoology, Institute of Biology, University of Bialystok, \\ Świerkowa 20B, PL-15-950 Białystok, Poland; e-mail: marcins@uwb.edu.pl \\ ${ }^{3}$ Ks. St. Konarskiego 15, PL-08-400 Garwolin, Poland
}

Key words. Lycaenidae, Phengaris arion, P. rebeli, genetic polymorphism, cross-amplification, Poland

\begin{abstract}
We analysed the polymorphism of cross-amplified microsatellite loci in two endangered butterflies of the genus Phengaris, which inhabit warm grasslands. Specimens of $P$. arion and P. 'rebeli' collected in Poland showed contrasting levels of variability in the investigated loci. All six tested microsatellites were highly variable in $P$. arion, whereas in $P$. 'rebeli' one locus was monomorphic and the other four loci showed a rather low level of polymorphism. Genetic differentiation was small or moderate among $P$. arion populations and high among $P$. 'rebeli' populations. We hypothesise that these differences reflect: (1) the relatively high genetic variability of $P$. arion compared with other members of the genus, indicated by previous studies on allozymes; (2) the small, in the majority of cases, genetic differentiation among populations of $P$. arion, which suggests recent gene flow; (3) a decrease in the genetic variability and increased isolation of peripheral populations of $P$. 'rebeli'. In both species, the occurrence of "null" alleles was suggested for some loci, which should be taken into consideration in future studies of the population structure. Additional analysis performed on the corrected frequency of alleles indicated that "null" alleles constitute only a minor problem when estimating genetic differentiation, using $F_{\mathrm{ST}}$ and AMOVA, however they strongly influence estimates of heterozygosity and $F_{\mathrm{IS}}$, and inferences about the number of genetic groups and assignment of individuals, especially in the case of ' $P$. rebeli'.
\end{abstract}

\section{INTRODUCTION}

Butterflies of the Palearctic genus Phengaris Doherty, which according to Fric et al. (2007) is a senior synonym of Maculinea Van Eecke, are among the most intensively studied insect species in Europe (Settele et al., 2005). This is mainly because of their conservation status, i.e. they are vulnerable or endangered in many countries (van Swaay \& Warren, 1999), and complicated and fascinating life history. These butterflies are on the wing in summer and females oviposit on the flower heads of specific plants. Caterpillars are phytophagous for only 2-3 weeks and when they reach the fourth (last) instar they leave the host-plants and drop to the ground. Continuation and completion of their development is possible only if larvae are encountered by foraging Myrmica ants, which pick them up and transport them to their nests. There, Phengaris caterpillars transform into social parasites, spending 11 months underground, or 23 if they take two years to complete their development. They exploit ant colonies, either preying directly on the ants' brood or being fed by the workers (Thomas, 1995; Thomas \& Settele, 2004).

Among European representatives of the genus, three species are considered as predators i.e. xerothermophilous $P$. arion (L.), whose larvae develop initially on Thymus spp. or Origanum vulgare, and P. teleius (Bgstr.) and $P$. nausithous (Bgstr.), which are rather hygrophilous butterflies associated with Sanguisorba officinalis. Much more sophisticated "cuckoo" feeding is recorded in $P$. alcon (Den. \& Schiff.) and $P$. rebeli (Hirschke) (Thomas, 1995; Thomas \& Elmes, 1998). However, the taxonomic status of these two species is disputed as recent genetic studies did not differentiate between them (Als et al., 2004; Pecsenye et al., 2007). Nevertheless, because of ecological differences and some developmental features it is suggested that they should be treated at least as distinct conservation units (Sielezniew \& Stankiewicz, 2007) and they are still considered as separate species in many studies. $P$. alcon inhabits humid meadows where its main larval food plant Gentiana pneumonanthe grows and $P$. rebeli is confined to dry calcareous grasslands with $G$. cruciata (Thomas, 1995). However, there are inconsistencies in recent papers concerning both the generic and specific names (compare e.g. Tartally et al., 2008; Árnyas et al., 2009; Barbero et al., 2009). In the present paper we call the controversial taxon $P$. 'rebeli' to avoid any possible confusion.

The relationships of Phengaris butterflies with ants used to be considered highly specific i.e. particular species survived best only in colonies of certain Myrmica species (Thomas et al., 1989). However, recent studies have revealed much more complicated patterns, including inter-specific and geographical variation in host-ant use, and in the degree of specificity. For example $P$. arion, which is supposed to be specific to M. sabuleti Mein., can 
also survive in the nests of other ants (Sielezniew \& Stankiewicz, 2008). On the other hand, in addition to the different host-races of $P$. 'rebeli' there are also populations that are not host specific (Steiner et al., 2003; Tartally et al., 2008; Sielezniew \& Dziekańska, 2009).

Larval food plants of Phengaris butterflies and populations of their host ants are very sensitive to changes in land use. Generally the habitats of Phengaris butterflies are dependent on extensively managed grasslands. Therefore, any change in land use, including intensifications, or on the other hand abandonment, can be highly destructive. In fragmented European landscapes, appropriate patches of habitat are becoming more and more rare and scattered, so most of the Phengaris populations are more or less isolated, especially as the dispersal ability of the butterflies is limited (Thomas, 1995; Nowicki et al., 2005; Settele et al., 2005).

Complex biology and ecology, an often unclear taxonomic status, together with the necessity for active conservation of many populations of Phengaris (Maculinea) butterflies, has resulted in researchers using genetic data in studies on these species. There is no doubt that the molecular techniques, which allow researchers to measure and characterize the pattern of distribution of genetic variability at the molecular level, have significantly increased our knowledge about members of the genus Phengaris (Maculinea). For example, allozyme data were used to analyse genetic differentiation among populations of four Phengaris species inhabiting eastern parts of Central Europe (Pecsenye et al., 2007), investigate the genetic structure of sympatric populations of $P$. nausithous and $P$. teleius (Figurny-Puchalska et al., 2000) and local populations of $P$. alcon on the Jutland peninsula (Gadeberg \& Boomsma, 1997), as well as resolve taxonomic uncertainties between $P$. alcon and $P$. 'rebeli' (Bereczki et al., 2005). In addition, mitochondrial gene sequences have served as a source of information for reconstructing the phylogeny of Phengaris/Maculinea taxa (Als et al., 2004).

Recently microsatellite markers were used in studies on Phengaris butterflies. Anton et al. (2007) used them to evaluate the level and pattern of gene flow among fragmented populations of $P$. nausithous and its specific parasitoid, and Nash et al. (2008) to characterize genetic differentiation among populations of $P$. alcon and its potential host ant species.

Microsatellite markers are widely used to investigate animal populations, enabling researchers to gain an insight into many different aspects of species biology and ecology (review in: Jarne \& Lagoda, 1996; Chistiakov et al., 2006; Selkoe \& Toonen, 2006). However, they are still not very commonly used in studies on Lepidoptera. One of the factors limiting an even wider use of microsatellites in studies on these insects is linked with the problems of isolating a set of loci suitable for a population genetic study (Nève \& Meglécz, 2000). This is probably due to the reduced frequency of microsatellites in the lepidopteran genome, the occurrence of microsatellite DNA families with very similar or identical flanking regions and the high frequency of "null" alleles, which result in extremely low cloning efficiency (Meglécz et al., 2004, 2007; Zhang, 2004 and references therein; van't Hof et al., 2007 and references therein).

In order to overcome technical problems, save time and reduce expense in such cases, a cross-species amplification strategy can be applied, based on using PCR primers described for microsatellite loci in one species (the source species) to amplify homologous microsatellites in other species (the target species). This concept is widely used and very useful, for example in taxa with a low frequency of microsatellites within a genome, such as birds (Primmer et al., 1996; Galbusera et al., 2000; Rutkowski et al., 2006). However, the application of cross-species microsatellite amplification has many limitations: the strategy works best for species belonging to the same genus or recently separated genera (Scribner \& Pearce, 2000) and in many cases a given microsatellite may fail to amplify or may be less or even non-polymorphic in target species (Rubinsztein et al., 1995; Morin et al., 1998). Thus, application of a cross-species strategy requires a preliminary study, which assess the amplification success of particular markers and their level of polymorphism in target species, as only polymorphic microsatellites can be successfully used in population or ecological studies (Frankham et al., 2003).

So far, in Large Blue butterflies, there are 11 microsatellite markers for $P$. nausithous and one for $P$. alcon (Zeisset et al., 2005), which have been successfully used in population studies (Anton et al., 2007; Nash et al., 2008). A cross-species experiment indicated that nine of these markers can be amplified in P. teleius with eight of them showing polymorphism, and four were amplified and appeared to be polymorphic in $P$. alcon (see Table 2 in Zeisset et al., 2005). Cross-species amplification is also recorded for $P$. arion and $P$. 'rebeli', however in both of them only success or failure of amplification is reported, as only one or two individuals were analysed. As far as $P$. arion is concerned, six loci were amplified and designated by Zeisset et al. (2005) as Macu8, Macu9, Macu11, Macu15, Macu16, and Macu 17. In ' $P$. rebeli' Macu5, Macu8, Macu11, Macu15, and Malc169 were successfully amplified (see Table 2 in Zeisset et al., 2005).

The aim of our study was to characterize the polymorphism of those successfully amplified microsatellite markers in relatively large samples of $P$. arion and $P$. 'rebeli', and assess the level of genetic diversity present within and between these two xerothermophilous butterflies. First, we determined the proportion of loci that were polymorphic, and hence could be used in population genetic studies on each of the species. Secondly, population level analyses of each species were used to determine whether "null" alleles are present at some loci and estimate their frequency. Thirdly, the level of genetic differentiation among populations within each species and hence the proportion of a species' genetic diversity resulting from differences among populations, were estimated. Fourthly, the indicators of microsatellite polymor- 
TABLE 1. Information on the locations sampled and sizes of the samples of $P$. arion and $P$. 'rebeli' collected in Poland.

\begin{tabular}{|c|c|c|c|c|c|}
\hline & Locality & Region & Coordinates & Elevation & Sample size \\
\hline \multirow{14}{*}{$\begin{array}{c}\text { Phengaris } \\
\text { arion }\end{array}$} & Gugny & Biebrza Basin & $53^{\circ} 19^{\prime} \mathrm{N} / 22^{\circ} 35^{\prime} \mathrm{E}$ & $100 \mathrm{~m}$ & 11 \\
\hline & Piaski & Narew valley & $53^{\circ} 13^{\prime} \mathrm{N} / 22^{\circ} 45^{\prime} \mathrm{E}$ & $105 \mathrm{~m}$ & 16 \\
\hline & Sośnia & Biebrza Basin & $53^{\circ} 29^{\prime} \mathrm{N} / 22^{\circ} 35^{\prime} \mathrm{E}$ & $110 \mathrm{~m}$ & 8 \\
\hline & Zalewsze & Podlasie & $51^{\circ} 52^{\prime} \mathrm{N} / 23^{\circ} 36^{\prime} \mathrm{E}$ & $160 \mathrm{~m}$ & 1 \\
\hline & Orchówek & Polesie & $51^{\circ} 31^{\prime} \mathrm{N} / 23^{\circ} 35^{\prime} \mathrm{E}$ & $150 \mathrm{~m}$ & 3 \\
\hline & Wola Uhruska & Polesie & $51^{\circ} 20^{\prime} \mathrm{N} / 23^{\circ} 37^{\prime} \mathrm{E}$ & $180 \mathrm{~m}$ & 3 \\
\hline & Hutki-Kanki & Kraków-Częstochowa Upland & $50^{\circ} 24^{\prime} \mathrm{N} / 19^{\circ} 30^{\prime} \mathrm{E}$ & $360 \mathrm{~m}$ & 13 \\
\hline & Biesak & Świętokrzyskie & $50^{\circ} 50^{\prime} \mathrm{N} / 20^{\circ} 35^{\prime} \mathrm{E}$ & $240 \mathrm{~m}$ & 1 \\
\hline & Suków & Świętokrzyskie & $50^{\circ} 47^{\prime} \mathrm{N} / 20^{\circ} 42^{\prime} \mathrm{E}$ & $250 \mathrm{~m}$ & 9 \\
\hline & Babice & Dynów Foothills & $49^{\circ} 49^{\prime} \mathrm{N} / 22^{\circ} 30^{\prime} \mathrm{E}$ & $250 \mathrm{~m}$ & 11 \\
\hline & Kluszkowce & Gorce Mts & $49^{\circ} 27^{\prime} \mathrm{N} / 20^{\circ} 19^{\prime} \mathrm{E}$ & $730 \mathrm{~m}$ & 18 \\
\hline & Sromowce & Pieniny Mts & $49^{\circ} 24^{\prime} \mathrm{N} / 20^{\circ} 24^{\prime} \mathrm{E}$ & $530 \mathrm{~m}$ & 1 \\
\hline & Zyndranowa & Beskid Niski Mts & $49^{\circ} 25^{\prime} \mathrm{N} / 21^{\circ} 44^{\prime} \mathrm{E}$ & $450 \mathrm{~m}$ & 3 \\
\hline & Zagórz & Beskid Niski Mts & $49^{\circ} 30^{\prime} \mathrm{N} / 22^{\circ} 16^{\prime} \mathrm{E}$ & $310 \mathrm{~m}$ & 1 \\
\hline \multirow{3}{*}{ P. 'rebeli' } & Przemyśl & Przemyśl Foothills & $49^{\circ} 46^{\prime} \mathrm{N} / 22^{\circ} 46^{\prime} \mathrm{E}$ & $340 \mathrm{~m}$ & 38 \\
\hline & Smolnik & Bieszczady Mts & $49^{\circ} 15^{\prime} \mathrm{N} / 22^{\circ} 07^{\prime} \mathrm{E}$ & $530 \mathrm{~m}$ & 15 \\
\hline & Sromowce & Pieniny Mts & $49^{\circ} 24^{\prime} \mathrm{N} / 20^{\circ} 24^{\prime} \mathrm{E}$ & $530 \mathrm{~m}$ & 15 \\
\hline
\end{tabular}

phism at three loci common to both the species studied, were compared.

\section{MATERIAL AND METHODS}

\section{Sample collection}

$P$. arion is widely distributed in the Palaearctic while $P$. 'rebeli' is restricted to Europe (Pech et al., 2004). Material for the present study was obtained from Poland. We collected 99 individuals of Phengaris (Maculinea) arion and 68 individuals of $P$. 'rebeli'. Individuals of $P$. arion were collected in July, between 2005 and 2007, at 16 sites in southern and eastern Poland, i.e. throughout its present distribution range in this country (Sielezniew et al., 2005). Details are given in Table 1 and locations of the sampled populations are presented in Fig 1. Adult butterflies with heavily worn wings, i.e. hypothetically at the end of their lives, were caught and placed in $96 \%$ alcohol. Fragments of thorax were used as a source of DNA.

Distribution of $P$. 'rebeli' in Poland is restricted to a dozen or so sites in the south-east (Sielezniew \& Dziekańska, 2009) and material was sampled from three sites (Table 1 and Fig. 1) in the three main distribution areas, which are also the northernmost in Central Europe. The material consisted of caterpillars obtained in late July 2007 from their food plants, i.e. shoots of Gentiana cruciata with eggshells. To reduce any possible negative effect the plants were collected only from patches where caterpillars did not have any chance of survival after dropping to the ground, i.e. those growing outside the foraging zone of Myrmica ants. Such areas were identified by placing sugar baits near occupied plants. Cut shoots put in plastic cups with water remained fresh for about two weeks. Just-emerged fourth instar caterpillars were successively put in $96 \%$ alcohol and then used for genetic analyses.

We collected many Gentiana shoots (about 30), some of which bore many eggs although they are laid singly by particular females (Thomas, 1995). Therefore, every plant certainly hosted the offspring of many females, and it is unlikely that only one or a few families were included in the analyses.

\section{Laboratory procedures}

DNA was extracted from approx. $0.5 \mathrm{~cm}$ long fragments of thorax $(P$. arion) and half of each larva $(P$. 'rebeli'). The remaining parts of samples were stored dry in separate vials (at $-72^{\circ} \mathrm{C}$ ) as reference material. For extraction we used Genomic
Mini kit (A\&A Biotechnology, Gdańsk, Poland) applying the manufacturers procedure for fresh tissue samples. Briefly, each sample was physically fragmented using a sterile scalpel and placed in a tube containing $200 \mu \mathrm{l}$ of lysis buffer and $20 \mu \mathrm{l}$ of proteinase $\mathrm{K}$ solution, and incubated overnight at $50^{\circ} \mathrm{C}$. Then, extraction followed the standard protocol. Finally, DNA was eluted in $200 \mu \mathrm{l}$ of elution buffer.

Using the PCR reaction we amplified 6 microsatellite loci for $P$. arion, designated by Zeisset et al. (2005) as Macu8, Macu9, Macu11, Macu15, Macu16, and Macu17, and 5 microsatellite loci for P. 'rebeli': Macu5, Macu8, Macu11, Macu15, and Malc169, using primers described by the authors. All microsatellites were simple dinucleotide repeats, except for Macu16, which was a compound dinucleotide repeat (Zeisset et al., 2005).

Each reaction was performed in $25 \mu$ of reaction mix, which contained: $10 \mathrm{pmol}$ of each primer, $1.5 \mu \mathrm{l}$ of DNA extract, 12.5

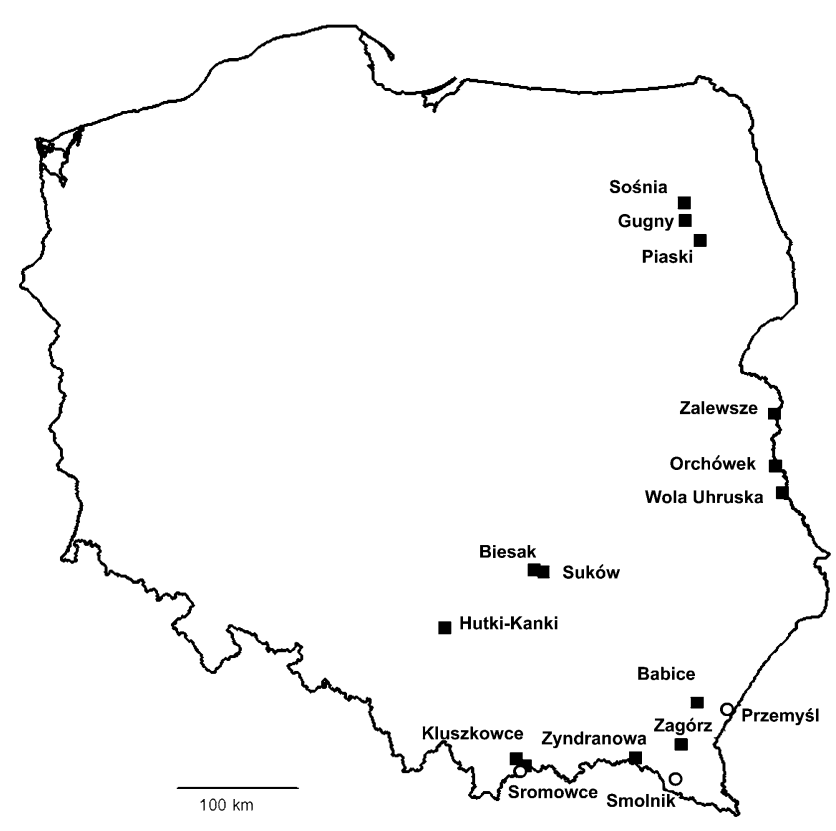

Fig. 1. Location of the sampling sites in Poland: $\mathbf{\square}-P$. arion, O-P. 'rebeli'. 
TABle 2. Characterization of six microsatellite loci amplified in the total sample of $P$. arion $(n=99)$ and $P$. 'rebeli' $(n=68)$. Size range - size of fragments obtained during PCR, including flanking region; $A$ - number of alleles; $H_{\mathrm{O}}$ - heterozygosity observed; $H_{\mathrm{E}}$ - heterozygosity expected; $F_{\mathrm{IS}}$ - fixation index. ${ }^{*}$ - significant $F_{\mathrm{IS}}$ value after Bonferroni correction (Bonferroni corrected P-value at $\alpha=0.05$ was 0.0083 for $P$. arion and 0.01 for $P$. rebeli); $\mathrm{Nc}-$ not calculated.

\begin{tabular}{ccccccc}
\hline & Locus & Size range & $A$ & $H_{\mathrm{O}}$ & $H_{\mathrm{E}}$ & $F_{\mathrm{IS}}$ \\
\hline \multirow{5}{*}{ P. arion } & Macu8 & $182-242$ & 19 & 0.808 & 0.844 & 0.048 \\
& Macu9 & $160-212$ & 22 & 0.869 & 0.930 & $0.071^{*}$ \\
& Macu11 & $176-218$ & 13 & 0.434 & 0.600 & $0.280^{*}$ \\
& Macu15 & $136-182$ & 10 & 0.646 & 0.732 & 0.121 \\
& Macu16 & $296-314$ & 8 & 0.260 & 0.510 & $0.493^{*}$ \\
& Macu17 & $222-274$ & 23 & 0.727 & 0.877 & $0.175^{*}$ \\
\hline & Mean & & 15.8 & 0.624 & 0.749 & $0.171^{*}$ \\
\hline P. 'rebeli' & Macu5 & $206-220$ & 3 & 0.04 & 0.49 & $0.91^{*}$ \\
& Macu8 & 206 & 1 & 0.00 & 0.00 & Nc \\
& Macu11 & $196-238$ & 4 & 0.24 & 0.48 & $0.50^{*}$ \\
& Macu15 & $152-206$ & 8 & 0.22 & 0.74 & $0.71^{*}$ \\
& Malc169 & $212-234$ & 3 & 0.15 & 0.19 & 0.21 \\
\hline
\end{tabular}

$\mu 1$ of REDTaq PCR ReadyMix (Sigma-Aldrich, Poznań, Poland) and $7.5 \mu \mathrm{l}$ of PCR grade water (Sigma-Aldrich). Forward primers were fluorescently labelled on their 5' ends with one of the following labels: Dye2, Dye3 or Dye4 (SigmaAldrich). Prior to PCR, reagents, tubes and pipettes were exposed to ultraviolet light for $15 \mathrm{~min}$. The following PCR profiles were used in a Techne Touchgene thermocycler for amplifying Macu5, Macu8, Macu9, Macu11, Macu15, and Malc169: initial denaturation for $3 \mathrm{~min}$. at $94^{\circ} \mathrm{C}$, followed by 34 cycles: 1 min at $94^{\circ} \mathrm{C} ; 45 \mathrm{~s}$ at $55^{\circ} \mathrm{C}, 45 \mathrm{~s}$ at $72^{\circ} \mathrm{C}$; and one cycle: $1 \mathrm{~min}$ at $94^{\circ} \mathrm{C} ; 45 \mathrm{~s}$ at $55^{\circ} \mathrm{C}, 5 \mathrm{~min}$ at $72^{\circ} \mathrm{C}$. For amplifying Macu 16 and Macu 17 the annealing temperature was $63^{\circ} \mathrm{C}$ and the remaining PCR conditions were similar.

The length of amplified fragments and identification of microsatellite alleles was done using a CEQ8000 Beckman Coulter automated sequencer (Comesa, Warsaw, Poland). Data were analysed using Beckman Coulter Fragment Analysis Software.

\section{Statistical analysis}

Analysis of the molecular data was done at a few different levels. First, we described the microsatellite polymorphism at the species level. In this analysis of both species, we described the overall size range of alleles, estimated allelic diversity $(A)$ and observed heterozygosity $\left(H_{\mathrm{O}}\right)$ and unbiased expected heterozygosity $\left(H_{\mathrm{E}}\right)($ Nei \& Roychoudhury, 1974) for each locus. Fixation index $\left(F_{\mathrm{IS}}\right)$ for each locus was calculated and its significance tested under 120 randomisations for $P$. arion, 100 randomisations for $P$. 'rebeli' and Bonferroni correction for multiple comparison. We also calculated the probability of genotypic linkage disequilibrium between all the pairs of loci within each species. These analyses were performed using GenAlEx version 6.0 (Peakall \& Smouse, 2001) and FSTAT version 2.9.3 (Goudet, 2001). Secondly, for each species, we analysed microsatellite polymorphism within and among populations. These analyses were performed only for populations for which more than 10 samples were collected. Thus, in the case of $P$. arion we included five populations and for $P$. 'rebeli' all three populations sampled (Table 1). Besides basic indicators of the population's genetic variability we also estimated genetic differentiation among sampling localities within each species using a variety of methods. Overall $(\theta)$ and pairwise $\left(F_{\mathrm{ST}}\right)$ (Weir $\&$ Cockerham, 1984) estimates of genetic differentiation were obtained from FSTAT version 2.9.3 (Goudet, 2001). Significance of pairwise $F_{\mathrm{ST}}$ was tested using 200 permutations ( $P$. arion) and 60 permutations ( $P$. 'rebeli'). To reduce the likelihood of type I errors among multiple tests we applied a Bonferroni correction. For $\theta$ we estimated $95 \%$ confidence intervals as implemented in FSTAT. Then, using the AMOVA procedure in Arlequin software (version 2.0; Schneider et al., 2000) we estimated the proportion of variance among and within populations. Stepwise mutation model (SMM) was assumed for evolution of microsatellite markers. The significance of the observed variance components was evaluated by means of a non-parametric permutation method (Excoffier et al., 1992) as executed in Arlequin.

Finally, we used a Bayesian-clustering method (STRUCTURE version 2; Pritchard et al., 2000) to examine how well predefined "populations" corresponded to genetic groups $(\mathrm{K})$. We ran Structure three times for each user-defined K (1-5 for $P$. arion and 1-3 for $P$. 'rebeli') with an initial burn in of 50000 and 100000 iterations of the total data set. We used the admixture model of ancestry and the correlated model of allele frequencies. The proportion of membership of each predefined "population" within each genetic group was estimated for $\mathrm{K}$ with the highest likelihood. Sampling location was not used as prior information.

Each population was also tested for the presence of "null" alleles using Micro-Checker (van Oosterhout et al., 2004). We performed this analysis only at the population level to avoid the influence of heterozygote deficiency caused by the Wahlund effect. Frequency of "null" alleles in each population was estimated using two methods in Micro-Checker: Oosterhout (van Oosterhout et al., 2004) and Brookfield (Brookfield, 1996). Using the same software, we estimated the adjusted frequencies of alleles in each population, taking into account the presence of "null" alleles. We used the van Oosterhout et al. (2004) method. Then we repeated the analysis at the population level, based on the corrected genotypes.

We compared microsatellite polymorphism in $P$. arion and $P$. 'rebeli' at three loci, which amplified in both species. In particular, we compared allelic richness, observed heterozygosity, $F_{\text {IS }}$ and $F_{\mathrm{ST}}$ between two groups of populations: Group I (five populations of $P$. arion; $n=69$, Table 3a) and Group II (three populations of $P$. 'rebeli', Table $3 \mathrm{~b}$ ), using a two-sided permutation test (1000 permutations) implemented in FSTAT. 
TABLE 3a. The characterization of the microsatellite polymorphism of $P$. arion from five populations $(n=69)$. $N-$ number of individuals for which this locus was successfully amplified; $A$ - number of alleles; $R$ - allelic richness; $H_{\mathrm{O}}$ - heterozygosity observed; $H_{\mathrm{E}}$ - heterozygosity expected; $F_{\mathrm{IS}}$ - fixation index; $F_{\mathrm{IS}}{ }^{\mathrm{O}}$ - fixation index for corrected genotypes using Oosterhout method; * - significant $F_{\text {IS }}$ value after Bonferroni correction (Bonferroni corrected P-value at $\alpha=0.05$ was 0.0017 ).

\begin{tabular}{|c|c|c|c|c|c|c|c|c|}
\hline Locality & Locus & $N$ & $A$ & $R$ & $\mathrm{Ho}$ & $\mathrm{He}$ & $F_{\text {IS }}$ & $F_{\text {IS }}{ }^{\mathrm{O}}$ \\
\hline \multirow{7}{*}{ Gugny } & Macu8 & 11 & 3 & 3 & 0.364 & 0.376 & 0.033 & 0.033 \\
\hline & Macu9 & 11 & 5 & 5 & 0.636 & 0.781 & 0.185 & 0.185 \\
\hline & Macu11 & 11 & 4 & 4 & 0.364 & 0.591 & 0.385 & 0.385 \\
\hline & Macu15 & 11 & 5 & 5 & 0.273 & 0.554 & 0.507 & 0.210 \\
\hline & Macu16 & 11 & 4 & 4 & 0.636 & 0.665 & 0.043 & 0.043 \\
\hline & Macu17 & 11 & 5 & 5 & 0.727 & 0.698 & -0.041 & -0.041 \\
\hline & Mean & & 4.33 & 4.33 & 0.500 & 0.611 & $0.227^{*}$ & 0.186 \\
\hline \multirow{7}{*}{ Piaski } & Macu8 & 16 & 8 & 7.27 & 0.938 & 0.816 & -0.148 & -0.148 \\
\hline & Macu9 & 16 & 13 & 11.22 & 0.875 & 0.896 & 0.024 & 0.024 \\
\hline & Macu11 & 16 & 8 & 6.88 & 0.500 & 0.754 & 0.337 & 0.077 \\
\hline & Macu15 & 16 & 5 & 4.28 & 0.563 & 0.541 & -0.040 & -0.040 \\
\hline & Macu16 & 14 & 5 & 4.88 & 0.214 & 0.513 & $0.582 *$ & 0.173 \\
\hline & Macu17 & 16 & 6 & 5.48 & 0.563 & 0.652 & 0.138 & 0.138 \\
\hline & Mean & & 7.50 & 6.67 & 0.609 & 0.695 & 0.157 & 0.067 \\
\hline \multirow{7}{*}{ Babice } & Macu8 & 11 & 7 & 7 & 0.818 & 0.785 & -0.042 & -0.042 \\
\hline & Macu9 & 11 & 11 & 11 & 0.909 & 0.888 & -0.023 & -0.023 \\
\hline & Macu11 & 11 & 3 & 3 & 0.273 & 0.244 & -0.119 & -0.119 \\
\hline & Macu15 & 11 & 6 & 6 & 0.909 & 0.707 & -0.287 & -0.287 \\
\hline & Macu16 & 11 & 3 & 3 & 0.182 & 0.541 & 0.664 & -0.054 \\
\hline & Macu17 & 11 & 8 & 8 & 0.727 & 0.818 & 0.111 & 0.111 \\
\hline & Mean & & 6.33 & 6.33 & 0.636 & 0.664 & 0.089 & -0.008 \\
\hline \multirow{7}{*}{ Kluszkowce } & Macu8 & 18 & 6 & 5.49 & 0.722 & 0.722 & 0.000 & 0.000 \\
\hline & Macu9 & 18 & 8 & 6.76 & 0.944 & 0.796 & -0.186 & -0.186 \\
\hline & Macu11 & 18 & 4 & 3.85 & 0.611 & 0.568 & -0.076 & -0.076 \\
\hline & Macu15 & 18 & 4 & 3.99 & 0.778 & 0.735 & -0.059 & -0.059 \\
\hline & Macu16 & 18 & 2 & 1.86 & 0.000 & 0.105 & 1.000 & 1.000 \\
\hline & Macu17 & 18 & 8 & 6.92 & 0.833 & 0.799 & -0.042 & -0.042 \\
\hline & Mean & & 5.33 & 4.81 & 0.648 & 0.621 & -0.015 & -0.015 \\
\hline \multirow{7}{*}{ Hutki-Kanki } & Macu8 & 13 & 10 & 9.35 & 1.000 & 0.855 & -0.170 & -0.170 \\
\hline & Macu9 & 13 & 11 & 10.36 & 0.923 & 0.888 & -0.040 & -0.040 \\
\hline & Macu11 & 13 & 6 & 5.52 & 0.462 & 0.645 & 0.284 & 0.284 \\
\hline & Macu15 & 13 & 8 & 7.53 & 0.846 & 0.799 & -0.059 & -0.059 \\
\hline & Macu16 & 13 & 4 & 3.84 & 0.231 & 0.438 & 0.473 & 0.125 \\
\hline & Macu17 & 13 & 9 & 8.48 & 0.769 & 0.828 & 0.071 & 0.071 \\
\hline & Mean & & 8.00 & 7.51 & 0.705 & 0.742 & 0.090 & 0.060 \\
\hline
\end{tabular}

\section{RESULTS}

\section{P. arion - species level}

We failed to amplify Macu16 in three samples despite several repeats and applying a wide range of annealing temperatures $\left(47-60^{\circ} \mathrm{C}\right)$ and number of PCR cycles (up to 45). Two of them were collected at Piaski (NE Poland) and one at Orchówek (E Poland). Remaining microsatellites were successfully amplified in all individuals tested $(n=99)$. All six microsatellites were found to be polymorphic with 8 (Macu16) to 23 (Macu17) alleles (Table 2). In total 95 alleles were detected. In four out of six microsatellites, $F_{\text {IS }}$ was significantly higher than zero indicating heterozygote deficiency. Accordingly, the overall $F_{\text {IS }}$ value was higher than zero and significant.

\section{$P$. arion - population level}

Comparison of populations where more than 10 samples were collected, indicated that the Gugny population had the lowest level of microsatellite polymorphism (in terms of $A, R$, and heterozygosities) (Table 3a). It was also the only population for which the overall $F_{\text {IS }}$ was significantly higher than zero. The highest values of indicators of microsatellite polymorphism were detected in the Hutki-Kanki population. In four out of five populations, the $F_{\text {IS }}$ for the Macu16 locus had a high positive value, indicating strong heterozygote deficiency, with the most striking example being the Kluszkowce population, where despite the presence of two alleles, no heterozygotes were found (Table 3a).

Analysis in Micro-Checker suggested the presence of "null" alleles in the Gugny population at locus Macu15, however because more than $50 \%$ of the homozygotes were of one allele size class, a bi-nominal analysis could not be performed. For Piaski, analysis indicated the presence of "null" alleles at Macu11 (combined probability $P$ $<0.025$ ) and suggested the presence of "null" alleles at Macu16 (more than $50 \%$ of homozygotes were of one allele size class, so a bi-nominal analysis could not be 
TABLE 3b. The characterization of the microsatellite polymorphisms of $P$. 'rebeli' from three populations. $N$ - number of individuals for which this locus was successfully amplified; $A$ - number of alleles; $R$ - allelic richness; $H_{\mathrm{O}}$ - heterozygosity observed; $H_{\mathrm{E}}$ - heterozygosity expected; $F_{\mathrm{IS}}$ - fixation index; $F_{\mathrm{IS}}{ }^{\mathrm{O}}$ - fixation index for corrected genotypes using Oosterhout method; * - significant $F_{\text {Is }}$ value after Bonferroni correction (Bonferroni corrected P-value at $\alpha=0.05$ was 0.0033 ); $\mathrm{Nc}$ - not calculated.

\begin{tabular}{|c|c|c|c|c|c|c|c|c|}
\hline Locality & Locus & $N$ & $A$ & $R$ & Ho & $\mathrm{He}$ & $F_{\text {IS }}$ & $F_{\mathrm{IS}}{ }^{\mathrm{O}}$ \\
\hline \multirow{6}{*}{ Przemyśl } & Macu5 & 38 & 1 & 1.00 & 0.000 & 0.000 & $\mathrm{Nc}$ & $\mathrm{Nc}$ \\
\hline & Macu8 & 37 & 1 & 1.00 & 0.000 & 0.000 & $\mathrm{Nc}$ & $\mathrm{Nc}$ \\
\hline & Macu11 & 38 & 3 & 2.34 & 0.105 & 0.288 & $0.634 *$ & -0.091 \\
\hline & Macu15 & 37 & 4 & 2.93 & 0.243 & 0.439 & 0.446 & -0.036 \\
\hline & Malc169 & 38 & 1 & 1.00 & 0.000 & 0.000 & $\mathrm{Nc}$ & $\mathrm{Nc}$ \\
\hline & Mean & & 2.20 & 1.77 & 0.070 & 0.156 & $0.560^{*}$ & -0.048 \\
\hline \multirow{6}{*}{ Smolnik } & Macu5 & 15 & 2 & 1.87 & 0.067 & 0.064 & -0.034 & -0.034 \\
\hline & Macu8 & 15 & 1 & 1.00 & 0.000 & 0.000 & $\mathrm{Nc}$ & $\mathrm{Nc}$ \\
\hline & Macu11 & 15 & 2 & 2.00 & 0.600 & 0.420 & -0.429 & -0.429 \\
\hline & Macu15 & 13 & 3 & 3.00 & 0.231 & 0.322 & 0.284 & 0.284 \\
\hline & Malc169 & 14 & 3 & 2.93 & 0.286 & 0.253 & -0.131 & -0.131 \\
\hline & Mean & & 2.20 & 2.16 & 0.237 & 0.212 & -0.080 & -0.080 \\
\hline \multirow{6}{*}{ Sromowce } & Macu5 & 15 & 2 & 2.00 & 0.133 & 0.231 & 0.423 & 0.423 \\
\hline & Macu8 & 15 & 1 & 1.00 & 0.000 & 0.000 & $\mathrm{Nc}$ & $\mathrm{Nc}$ \\
\hline & Macu11 & 14 & 2 & 2.00 & 0.214 & 0.375 & 0.429 & 0.429 \\
\hline & Macu15 & 14 & 3 & 2.93 & 0.143 & 0.304 & 0.529 & 0.062 \\
\hline & Malc169 & 13 & 2 & 2.00 & 0.462 & 0.426 & -0.083 & -0.083 \\
\hline & Mean & & 2.00 & 1.99 & 0.190 & 0.267 & 0.321 & 0.200 \\
\hline
\end{tabular}

performed); for Babice "null" alleles were detected at Macu16 $(P<0.001)$ and possibly present at this locus in the Hutki-Kanki population. The frequency of "null" alleles in each population are presented in Table 4.

Analysis based on the data set with adjusted allele frequencies indicated no significant $F_{\text {IS }}$ either overall or for a particular locus in any population (Table $3 a$ ).

Analysis of genetic differentiation among the populations of $P$. arion investigated indicated moderate overall differentiation $(\theta=0.102$; CI 95\% $=0.071-0.139$; and for adjusted allele frequencies $\theta=0.104$; CI $95 \%=$ $0.073-0.137)$. Pairwise $F_{\mathrm{ST}}$ showed small genetic differentiation for the majority of comparisons, with the highest value $\left(F_{\mathrm{ST}}=0.23\right)$ for Kluszkowce and Gugny. The smallest differentiation was found between the Piaski and Hutki-Kanki populations. Pairwise $F_{\mathrm{ST}}$ values for corrected genotypes were very similar (Table 5a). AMOVA indicated that the main part of the variation was explained by differentiation within populations $(\mathrm{Vb}=89 \% ; P<$ 0.01) (Table 6). AMOVA results for corrected genotypes were identical.
In the STRUCTURE analysis likelihoods were consistent among runs (Table 7a). Assuming an admixture model of individuals' ancestry, the highest likelihood was shown for three genetic groups, independent of whether the original or corrected genotypes were used. $96 \%$ of the Gugny population was assigned to the first group, however $25-28 \%$ and $19-20 \%$ (depending on the run) of the Piaski population was also assigned to this group, for original and corrected genotypes, respectively. The second clade was composed of individuals from Piaski (60\% and $70 \%$ of individuals from this population were assigned to this clade for original and corrected genotypes, respectively), Babice (for which it was $75 \%$ and $76 \%$ ) and Hutki-Kanki (for which it was more than $80 \%$ and $85 \%$ ). The third clade was composed almost exclusively of individuals from the Kluszkowce population (almost $90 \%$ and $92 \%$ of individuals from this population were assigned to this clade, for original and corrected genotypes, respectively). Individual assignments are presented in Fig. 2. Because results of analysis in STRUCTURE were very similar for original and corrected genotypes, we present only individual assignment for corrected genotypes.

TABLE 4. Estimated frequency of "null" alleles in the populations of $P$. arion and $P$. 'rebeli' investigated.

\begin{tabular}{|c|c|c|c|c|c|}
\hline & Population & Locus & Oosterhout & Brookfield 1 & Brookfield 2 \\
\hline \multirow{5}{*}{ P. arion } & Gugny & Macu15 & 0.24 & 0.18 & 0.18 \\
\hline & Piaski & Macu11 & 0.17 & 0.14 & 0.14 \\
\hline & Piaski & Macu16 & 0.28 & 0.20 & 0.40 \\
\hline & Babice & Macu16 & 0.30 & 0.23 & 0.23 \\
\hline & Kluszkowce & - & - & - & - \\
\hline \multirow{5}{*}{ P. 'rebeli' } & Hutki-Kanki & Macu16 & 0.19 & 0.14 & 0.14 \\
\hline & Przemyśl & Macu11 & 0.24 & 0.14 & 0.14 \\
\hline & Przemyśl & Macu15 & 0.20 & 0.14 & 0.21 \\
\hline & Smolnik & - & - & - & - \\
\hline & Sromowce & Macu15 & 0.23 & 0.12 & 0.29 \\
\hline
\end{tabular}


TABLE 5a. Among-locality genetic differentiation (pairwise $F_{\mathrm{ST}}$ ) for $P$. arion. Only localities with more than 10 samples were considered. All values are significant (Bonferroni corrected P-value at $\alpha=0.05$ was 0.005 ). Below diagonal $-F_{\mathrm{ST}}$ for original genotypes; above diagonal $-F_{\mathrm{ST}}$ for corrected genotypes using Oosterhout method.

\begin{tabular}{lccccc}
\hline & Gugny & Piaski & Babice & Kluszkowce & Hutki-Kanki \\
\hline Gugny & & 0.111 & 0.106 & 0.220 & 0.091 \\
Piaski & 0.117 & & 0.082 & 0.105 & 0.027 \\
Babice & 0.110 & 0.092 & & 0.135 & 0.062 \\
Kluszkowce & 0.229 & 0.094 & 0.126 & & 0.081 \\
Hutki-Kanki & 0.112 & 0.028 & 0.075 & 0.072 & \\
\hline
\end{tabular}

We found significant linkage disequilibrium for three combinations of loci (Macu8 and Macu16; Macu9 and Macu11, Macu9 and Macu15) at the species level but not at the population level. Hence, we supposed that the observed linkage among loci was an outcome of population structure within the species.

\section{P. 'rebeli' - species level}

We failed to amplify Macu8 in one individual from Przemyśl, Macul1 in one individual from Sromowce, Macu15 in four individuals from all three populations and Macu169 in three individuals (two from Sromowce and one from Smolnik). For these samples we applied a wide range of annealing temperatures $\left(47-60^{\circ} \mathrm{C}\right)$ and number of PCR cycles (up to 45) and performed three independent PCR reactions for each combination of conditions. Four out of five microsatellites analysed were polymorphic with nine (Macu15) to three alleles (Macu5 and Malc169) (Table 2). In total 20 alleles were detected. At three out of four polymorphic loci $F_{\text {IS }}$ values were very high and significant. Accordingly, the total $F_{\text {Is }}$ value was also higher than zero and significant (Table 2).

\section{P. 'rebeli' - population level}

A low level of microsatellite polymorphism (in terms of $A, R$, and heterozygosities) was observed in each of the populations investigated (Table $3 \mathrm{~b}$ ). Whereas mean values of $A$ and $R$ did not differ distinctly among populations, the lowest percentage of polymorphic loci was recorded at Przemyśl where it was $40 \%$ rather than the $80 \%$ at Sromowce and Smolnik. The overall $F_{\text {IS }}$ values were significantly higher than zero in two populations (Przemyśl and Sromowce). $F_{\text {IS }}$ values for particular loci were significant for two polymorphic loci in the Przemyśl population. Analysis in Micro-Checker suggested the presence of "null" alleles both for polymorphic loci at Przemyśl and Macu15 in the Sromowce population. Because in all cases more than $50 \%$ of the homozygotes were of one allele size class, bi-nominal analyses were

TABLE 5b. Among-locality genetic differentiation (pairwise $\left.F_{\mathrm{ST}}\right)$ for $P$. 'rebeli'. All values are significant (Bonferroni corrected $\mathrm{P}$-value at $\alpha=0.05$ was 0.016 ). Below diagonal $-F_{\mathrm{ST}}$ for original genotypes; above diagonal $-F_{\mathrm{ST}}$ for corrected genotypes using Oosterhout method

\begin{tabular}{lccc}
\hline & Przemyśl & Smolnik & Sromowce \\
\hline Przemyśl & & 0.642 & 0.652 \\
Smolnik & 0.697 & & 0.201 \\
Sromowce & 0.716 & 0.201 & \\
\hline
\end{tabular}

not performed. The frequency of "null" alleles in both populations at each locus are presented in Table 4.

Analysis based on the data set with adjusted allele frequencies indicated no significant $F_{\text {IS }}$ either overall or for a particular locus in any population (Table $3 \mathrm{~b}$ ).

Analysis of genetic differentiation among the populations of $P$. 'rebeli' investigated indicated very strong overall differentiation $(\theta=0.644$; CI $95 \%=0.381-0.836$ for original genotypes and $\theta=0.533$; CI $95 \%=$ $0.287-0.843$ for corrected genotypes). Pairwise $F_{\text {ST }}$ showed high genetic differentiation among populations (Table 5b). AMOVA indicated that the main part of the variation was explained by differentiation among populations $(\mathrm{Va}=65 \%$ for original genotypes and $\mathrm{Va}=60 \%$ for corrected genotypes) (Table 6). The STRUCTURE analysis indicated three genetic groups (Table $7 \mathrm{~b}$ ). Individual assignment (Fig. 3a) placed all the individuals from Przemyśl in two genetic groups with equal probability. The third genetic group consists of individuals from Smolnik and Sromowce. In the case of corrected genotypes, different results were obtained. The STRUCTURE analysis indicated two genetic groups (Table $7 \mathrm{~b}$ ). Individuals from Przemyśl were assigned to the first group, whereas individuals from Smolnik and Sromowce (Fig 3b) were assigned to the second.

Significant linkage disequilibrium was found for all combinations of polymorphic loci at the species level but not at the population level. As in P. arion, the observed linkage among loci could be an outcome of the population structure within the species.

\section{$P$. arion vs. $P$. 'rebeli'}

Comparison of results obtained for three microsatellite loci common to both the species studied indicated that the level of polymorphism was significantly higher in populations of $P$. arion than $P$. 'rebeli' $(P=0.02$ for $R$; $P=0.02$ for $\mathrm{H}_{\mathrm{O}}$ ) for original as well as corrected genotypes. The $F_{\text {IS }}$ value was significantly higher in $P$. 'rebeli' $(P=$ 0.03 ), but only for original genotypes.

\section{DISCUSSION}

For Lepidoptera the level of cross-amplification success and ratio of polymorphic loci among those amplified differs significantly among experiments. For example, no successful amplification was reported in cross-amplification of microsatellites from Erynnis propertius in E. pacuvius (Hesperiidae) and it was very low in three other members of the genus (6-33\%), however in E. tristis it was quite high (85\%), with a substantial ratio of polymorphic loci among those amplified (58\%) (Zakharov et al., 
TABLE 6. AMOVA results for five populations of $P$. arion $(n=69)$ and three populations of $P$. 'rebeli' $(n=68)$.

\begin{tabular}{clcccc}
\hline & Source of variation & d.f. & Sum of squares & Variance components & Percentage of variation \\
\hline \multirow{3}{*}{ P. arion } & Among populations [Va] & 4 & 34.862 & 0.24364 & 10.58 \\
& Within populations [Vb] & 133 & 273.920 & 2.05955 & 89.42 \\
\hline \multirow{3}{*}{ P. 'rebeli' } & Total & 137 & 308.783 & 2.30319 & 64.38 \\
& Among populations [Va] & 2 & 40.495 & 0.49748 & 35.62 \\
& Within populations [Vb] & 133 & 36.615 & 0.27530 & 0.77278 \\
\hline
\end{tabular}

2007). Another example of low cross-amplification success are 22 microsatellites from Cydia pomonella. Only $18-27 \%$ of these microsatellites were amplified in two other species from the same genus and only $13 \%$ of those were polymorphic (Franck et al., 2005). This is to be expected as the microsatellites flanking regions differ between Lepidoptera species (Meglecz et al., 2004). However, they tend to be more similar in closely related species. Typically, the success of cross-amplification within a genus is rather high (60-100\%), with $40 \%$ to $100 \%$ of the polymorphic loci among all loci tested (e.g. Fauvelot, 2005; Mavárez \& González, 2006).

A previous study on Phengaris (Maculinea) in which microsatellites from $P$. nausithous were cross-amplified in P. teleius and P. alcon, reported $83 \%$ and $33 \%$ of amplified loci and $75 \%$ and $33 \%$ of polymorphic loci among those tested, respectively (Zeisset et al., 2005). In the case of $P$. arion and $P$. 'rebeli', cross-amplification was more successful in the case of the former (success of amplification approx. 55\% in $P$. arion versus $36 \%$ in $P$. 'rebeli'). Our study confirmed this tendency as all six loci that were successfully amplified in $P$. arion were polymorphic $[100 \%$ of the polymorphic loci among those successfully amplified and including data of Zeisset et al. (2005) 55\% of all those tested], while in $P$. 'rebeli' three out of four amplified loci were polymorphic $(75 \%$ of the polymorphic loci among those successfully amplified and only $25 \%$ of all those tested). Moreover, among amplified loci, $P$. arion had a higher level of polymorphism, in terms of allelic diversity and hetrozygosities, than $P$. 'rebeli'.

These results can be explained by two factors. First, as analysis of mitochondrial genes suggest (Als et al., 2004), $P$. arion is more closely related to the source species $(P$. nausithous) than $P$. 'rebeli'. It was shown that success of amplification of a locus in cross-species strategy and the probability of a locus being polymorphic was higher when genetic distance, estimated using cytochrome $b$

TABLE 7a. Inference of the number of genetic groups $(\mathrm{K})$ and likelihoods $(\operatorname{Ln} \operatorname{Pr}(\mathrm{X} \mid \mathrm{K})$ for each value of $\mathrm{K}$ among runs for $P$. arion using STRUCTURE (100,000 iterations, burn-in 50,000). Analysis based on corrected genotypes.

\begin{tabular}{cccc}
\hline \multirow{2}{*}{$\mathrm{K}$} & \multicolumn{3}{c}{$\operatorname{Ln} \operatorname{Pr}(\mathrm{X} \mid \mathrm{K})$} \\
\cline { 2 - 4 } & Run 1 & Run 2 & Run 3 \\
\hline 1 & -1667.2 & -1675.5 & -1689.2 \\
2 & -1587.9 & -1584.7 & -1587.4 \\
3 & -1541.9 & -1542.8 & -1542.1 \\
4 & -1642.0 & -1629.1 & -1627.5 \\
5 & -1746.5 & -1611.6 & -1684.5 \\
\hline
\end{tabular}

sequence divergence, between source and target species, was small (Primmer et al., 2005). Increasing phylogenetic distance may lead to the accumulation of mutations in flanking regions, and subsequently, to the occurrence of "null" alleles or unusable microsatellite markers (Harr et al., 1998). Thus, the higher success and higher polymorphism of cross-amplified markers in $P$. arion might be explained by a closer phylogenetic relationship with the source species.

Secondly, there is another factor, which could influence polymorphism of microsatellites in $P$. 'rebeli'. The samples were obtained from one region, which could be considered to be at the northern edge of the range of this butterfly in Central Europe. Many studies have indicated a lower genetic diversity, in terms of microsatellite polymorphism, in peripheral populations relative to core populations (Rossiter et al., 2000; Bouzat \& Johnson, 2004; Faugeron et al., 2004; Arnaud-Haond et al., 2006). If this is the case then more intensive sampling over a wider range of the species distribution should result in more alleles being identified in the loci analysed.

On the other hand, a comparative study based on allozymes indicated greater genetic variability in $P$. arion than in four other species of Phengaris (Maculinea) (Pescenye et al., 2007). Comparison of our results with data for $P$. nausithous, $P$. teleius, and $P$. alcon from other studies confirmed this observation. For example, Zeisset et al. (2005) report five alleles at Macu17 for 38 individuals of $P$. nausithous ( 0.13 alleles per individual), whereas we found from five to nine alleles at this locus in a single population of $P$. arion, where sample size did not exceed 20 individuals (from 0.16 to 0.69 alleles per individual). In another study, where large samples (25-38 individuals) of $P$. nausithous from 19 localities were analysed, three alleles were detected at locus Macu11 (Anton

TABLE 7b. Inference of the number of genetic groups $(\mathrm{K})$ and likelihoods $(\operatorname{Ln} \operatorname{Pr}(\mathrm{X} \mid \mathrm{K})$ for each value of $\mathrm{K}$ among runs for $P$. 'rebeli' using STRUCTURE (100,000 iterations, burn-in $50,000)$.

\begin{tabular}{|c|c|c|c|c|c|c|}
\hline \multirow{3}{*}{ K } & \multicolumn{6}{|c|}{$\operatorname{Ln} \operatorname{Pr}(\mathrm{X} \mid \mathrm{K})$} \\
\hline & \multicolumn{3}{|c|}{ Original genotypes } & \multicolumn{3}{|c|}{ Corrected genotypes } \\
\hline & Run 1 & Run 2 & Run 3 & Run 1 & Run 2 & Run 3 \\
\hline 1 & -475.4 & -470.0 & -471.9 & -535.6 & -535.0 & $\begin{array}{c}-533 . \\
8\end{array}$ \\
\hline 2 & -276.8 & -277.0 & -276.8 & -342.7 & -342.4 & $\begin{array}{c}-342 . \\
3\end{array}$ \\
\hline 3 & -272.2 & -270.9 & -270.9 & -346.9 & -347.4 & $\begin{array}{c}-347 . \\
9\end{array}$ \\
\hline
\end{tabular}




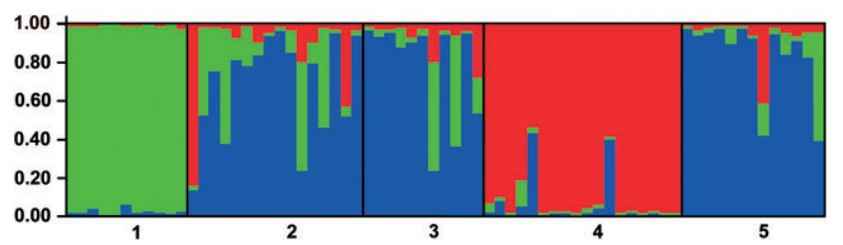

Fig 2. Probability of assigning individuals of $P$. arion to one of the three genetic groups without using prior population information for corrected genotypes. Each bar represents the estimated posterior probability of each individual butterfly belonging to each of the inferred clusters: green - Cluster I, blue - Cluster II, red - Cluster III. Solid black lines define the boundaries between the five populations, used in the analysis: 1 - Gugny, 2 - Piaski, 3 - Babice, 4 - Kluszkowce, 5 - HutkiKanki.

et al., 2007), compared to 13 alleles in 99 individuals of $P$. arion in this study.

This is unexpected, as many studies comparing homologous loci in different species report higher polymorphism in the source species, for which primers were characterised first (Jarne \& Lagoda, 1996), including invertebrates (Hutter et al., 1998; Luna et al., 2001; Rutkowski et al., 2007). Similarly, a higher polymorphism is recorded in $P$. arion for the majority of loci it shares with $P$. teleius and $P$. alcon [see Table 2 in Zeisset et al. (2005)]. We suggest that populations of $P$. arion have a higher level of genetic variability than other members of the genus, however confirmation of this and its explanation requires further study, involving sympatric populations and more comparable sample sizes. Conversely, $P$. alcon (including $P$. 'rebeli') is reported to be less polymorphic than other lycaenid butterflies (Bereczki et al., 2005).

It is possible that the effective population size of $P$. arion is higher than that of other members of the genus, especially $P$. alcon and $P$. 'rebeli'. Larval food plants of the latter two taxa, i.e. gentians, are usually distributed patchily at sites and are usually heavily loaded with eggs. Therefore many "cuckoo" caterpillars may be adopted by one colony and therefore experience contest competition. As far as $P$. arion is concerned the distribution of larval food plants i.e. Thymus species, and hence of caterpillars, is usually more even. Larvae of $P$. arion are also less advanced social parasites with "scramble" competition (Thomas \& Elmes, 1998). For the above reasons variation in reproductive success reducing effective population size is more plausible for $P$. alcon and $P$. 'rebeli' than $P$. arion.

As the analysis at the population level indicated that in both species at least some loci are affected by "null" alleles. In $P$. arion, depending on the method used, the frequency of "null" alleles varies from $14 \%$ to $40 \%$. Locus Macu16 seems to be especially vulnerable to this problem, as "null" alleles were present at this locus in three out of the five populations analysed. In $P$. 'rebeli' "null" alleles were present in two out of three populations. In both of them Macu15 was indicated as bearing "null" alleles. Interestingly, heterozygote deficit was indicated for this locus in the source species, $P$. nau-
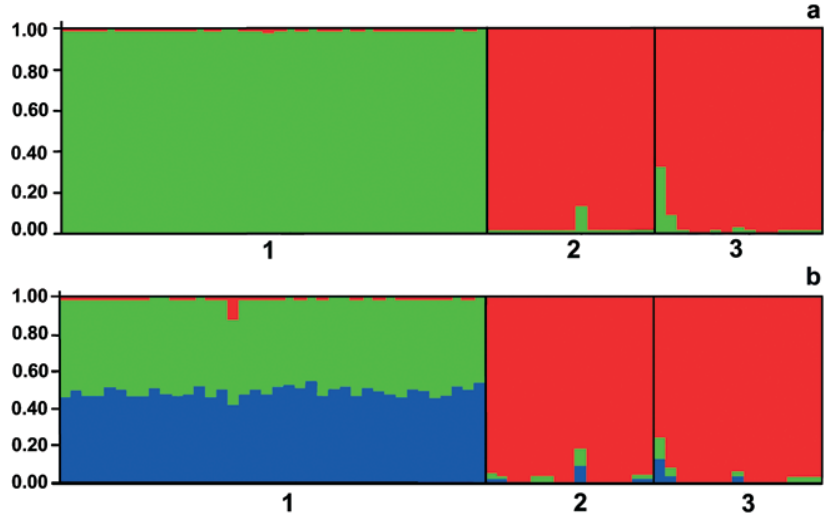

Fig 3. Probability of assigning individuals of $P$. 'rebeli' to two (a) or three (b) genetic groups based on corrected and original genotypes, respectively, without using prior population information. Each bar represents the estimated posterior probability of each individual butterfly belonging to each of the inferred clusters: green - Cluster I, red - Cluster II, blue Cluster III. Solid black lines define the boundaries between the three populations used in the analysis: 1 - Przemyśl, 2 - Smolnik, 3 - Sromowce.

sithous (Anton et al., 2007), but only at one out of 22 localities studied; and in P. teleius and P. alcon (Zeisset et al., 2005). Moreover, quite a high frequency of "null" alleles at this locus in P. arion was also indicated by our results. Thus, "null" alleles at Macu15 are a real problem, irrespective of the species studied. We suggest that when studying Phengaris butterflies one should bear in mind the presence of "null" alleles, estimate their frequency and then do an analysis using corrected genotypes. The comparison of results obtained using original and corrected genotypes indicated that the problem is especially important in $P$. 'rebeli'. Whereas the presence of "null" alleles seems to influence only the estimate of the inbreeding coefficient in $P$. arion, adjusting the frequency of alleles clearly changed the number of genetic groups and assignment of individuals within $P$. 'rebeli'.

For each of the species we found a contrasting level of within-population differentiation. While in $P$. arion the majority of the genetic variability was explained by within-population differentiation, in $P$. 'rebeli' a greater proportion of the variability resulted from differentiation among populations. Pairwise comparisons in the case of the former species indicated moderate genetic differentiation among populations and very high and significant $F_{\text {ST }}$ values for the latter species, despite in some cases the geographical closeness of the localities sampled. Analysis in STRUCTURE indicated the presence of a population structure in both species, but in $P$. arion individuals from particular localities (presumed populations) were assigned to a few clades, which indicated a rather substantial level of population admixture. In contrast, this analysis indicated a very strong differentiation between $P$. 'rebeli' individuals from Przemyśl and two other populations. These results might indicate that $P$. arion is better at dispersing. Indeed, different levels of population subdivision are reported in two sympatric species of Lepidoptera, which differ in flight capability, indicating a smaller 
among-population differentiation in larger, hence more "mobile" species (Zakharov \& Hellmann, 2008).

The level of population differentiation in $P$. arion indicated by the present study (overall $F_{\mathrm{ST}}=0.110$ ) is almost identical to that reported for populations of the species from southern parts of Central Europe (overall $F_{\mathrm{ST}}=$ 0.097), based on an analysis of allozyme loci (Pecsenye et al., 2007). These results suggest a significant reduction in gene flow, which is not surprising as Polish populations of $P$. arion inhabit rather isolated localities usually separated from each other by vast areas of unsuitable habitat. On the other hand, because of the ecological variation we expected an even larger differentiation in this species. Polish populations differ in terms of larval food plants and host ant species (Sielezniew et al., 2005; Sielezniew \& Stankiewicz, 2008; M. Sielezniew, unpubl.). For example there was a significant, but very small genetic difference between the Kluszkowce population, where larvae developed initially on Thymus pulegioides and then in nests of M. sabuleti (M. Sielezniew, unpubl.), and Piaski where $T$. serpyllum is the food plant and the ant hosts three other Myrmica species (Sielezniew \& Stankiewicz, 2008). This suggests that gene flow between southern populations and north-eastern areas was recently rather intensive. Similarly, the lack of a clear pattern of genetic differentiation between groups of populations using different food plants was recently indicated for the Phengaris alcon/rebeli group (Bereczki et al., 2005).

Moreover, there was a high value of $F_{\mathrm{ST}}$ for the two populations from the north-east: Gugny and Piaski, despite the very small geographical distance between them. The Gugny population has some unique characteristics, as it consists of patches of raised dry land surrounded by fen communities, which are hostile to xerothermophilous species. It also has the lowest levels of allelic diversity, allelic richness and heterozygosity of the populations investigated. This suggests that the Gugny population is isolated from other populations, so these marked differences might be caused by genetic drift. Hence, we concluded that patterns of differentiation and factors affecting genetic differences among populations of $P$. arion require further study, based on a larger number of localities and individuals.

As far as $P$. 'rebeli' is concerned, the gene flow among the populations investigated seems to be strongly reduced. Again, this could be an effect of analyzing peripheral populations, which studies of other species indicate are highly differentiated (Bouza et al., 1999; Pedersen \& Loeschcke, 2001; Bouzat \& Johnson, 2004) and Lepidoptera are no exception (Zakharov \& Hellmann, 2008). On the other hand, a large proportion of the genetic variation explained by differences among populations is mainly due to the genetic distinction of the population at Przemyśl. Pairwise comparisons for this population were extremely high, whereas the $F_{\mathrm{ST}}$ for the Smolnik-Sromowce pair is included within the range observed for $P$. arion.

Przemyśl and Sromowce are contrasting populations in terms of the host ants. M. sabuleti and M. scabrinodis
Nyl. are the hosts at Przemyśl (Sielezniew \& Stankiewicz, 2007) while M. schencki Em. is the only host recorded at Sromowce (Sielezniew \& Dziekańska, 2009). However, such data for Smolnik is missing and therefore, it is not possible to conclude that the observed differentiation might be related to variation in host ant specificity. Moreover, in two populations (Przemyśl and Sromowce) we found high $F_{\text {IS }}$ values for the majority of loci, indicating heterozygote deficiency. Analysis of corrected genotypes suggested that this could be an effect of the presence of "null" alleles, as mentioned above, however a similar phenomenon is reported for $P$. alcon in Denmark (Gadeberg \& Boomsma, 1997). The authors used allozymes as a genetic marker, thus "null" alleles could not be the explanation in that case. Instead, they propose that the co-existence of two separate genetic pools associated with different ants might account for this observation.

It is also plausible that populations of $P$. 'rebeli' were strongly isolated from each other, which in addition to the low dispersal ability of the species, leads to genetic drift and inbreeding. The population at Sromowce was very small and this species has recently declined in abundance in the Polish part of the Pieniny Mts due to the cessation of grassland management there (Sielezniew \& Dziekańska, 2009). However, the Przemyśl population was present at the borders of the city and is isolated by a wide area of buildings, agriculture land, parks and forests. Moreover it is the former area of the fortress of Przemyśl, which was an arena of intensive warfare a century ago. Xerothermal grasslands at $P$. 'rebeli' sites could undergo dramatic changes causing bottlenecks in local butterfly populations.

Summarising this part of the study, we can state that the microsatellites described for $P$. nausithous can be used to investigate the population genetics of $P$. arion. In this species we found high polymorphism at all loci, which enabled the use of those markers even in fine-scale studies of genetic structure, level of migration, etc., especially when used with additional molecular markers, such as allozymes. In the case of $P$. 'rebeli', only three loci from $P$. nausithous were polymorphic. Additionally, one marker (Malc169), described for P. alcon (Zeisset et al., 2005), also showed polymorphism. Using only four or six microsatellites could hinder the appropriate characterization of population genetic structure, as at least 10 polymorphic loci are necessary to avoid erroneous inference in genetic population studies (Koskinen et al., 2004). On the other hand, studies based on three to seven microsatellite markers are not rare, especially of Lepidoptera, where identification of a large set of microsatellites could be difficult (e.g. Keyghobadi et al., 2005; Nash et al., 2005; Sigaard et al., 2008). Bearing in mind the relatively small number of loci and the presence of "null" alleles in $P$. arion and $P$. rebeli, there is no doubt that the search for additional markers in both species should be continued, however we can state that the microsatellites analyzed in this study provided a valuable additional "molecular tool", which supported the investigations 
based on more universal markers, such as allozymes or AFLPs.

ACKNOWLEDGEMENTS. This work was supported by the Ministry of Science and Higher Education of Poland (grant no 2 P04G 024 30). We are indebted to I. Dziekańska for help in sampling. We would like also to thank J. Buszko, C. Bystrowski, A. Górnicki, M. Gwardian, K. Frąckiel, P. Klimczuk, K. Pałka, T. Janik, and A. Warecki for precise site location and/or logistic support during field trips. Valuable comments and suggestions of two anonymous referees helped to improve the manuscript.

\section{REFERENCES}

Als T.D., Vila R., Kandul N.P., Nash D.R., Yen S.H., Hsu Y.F., Mignault A.A., Boomsma J.J. \& Pierce N.E. 2004: The evolution of alternative parasitic life histories in large blue butterflies. Nature 432: 386-390.

Anton C., Zeisset I., Musche M., Durka W., Boomsma J.J. \& Settele J. 2007: Population structure of a large blue butterfly and its specialist parasitoid in a fragmented landscape. Mol. Ecol. 16: 3828-3838.

Arnaud-Haond S., Teixeira S., Massa S.I., Billot C., Saenger P., Coupland G., Duarte C.M. \& Serrão E.A. 2006: Genetic structure at range edge: low diversity and high inbreeding in Southeast Asian mangrove (Avicennia marina) populations. Mol. Ecol. 13: 3515-3525.

Árnyas E., Bereczki J., Tóth A., Varga K., Pecsenye K., Tartally A., Kövics Gy., Karsa D. \& Varga Z. 2009: Oviposition preferences of Maculinea alcon as influenced by aphid (Aphis gentianae) and fungal (Puccinia gentianae) infestation of larval host plants. Ecol. Entomol. 34: 90-97.

Barbero F., Thomas J.A., Bonelli S., Balletto E. \& SchöNROGGE K. 2009: Queen ants make distinctive sounds that are mimicked by a Butterfly Social Parasite. Science 323: 782-785.

Bereczki J., Pecsenye K., Peregovits L. \& Varga Z. 2005: Pattern of genetic differentiation in the Maculinea alcon species group (Lepidoptera, Lycaenidae) in Central Europe. J. Zool. Syst. Evol. Res. 43: 157-165.

Bouza C., Arias J., Castro J., Sánchez L. \& Martínez P. 1999: Genetic structure of brown trout, Salmo trutta L., at the southern limit of the distribution range of the anadromous form. Mol. Ecol. 8: 1991-2001.

Bouzat J.L. \& Johnson K. 2004: Genetic structure among closely spaced leks in a peripheral population of lesser prairie-chickens. Mol. Ecol. 13: 499-505.

BROOKFIELD J.F. 1996: A simple new method for estimating null allele frequency from heterozygote deficiency Mol. Ecol. 5: 453-455.

Chistiakov D.A., Hellemans B. \& Volckaert F.A.M. 2006: Microsatellites and their genomic distribution, evolution, function and applications: a review with special reference to fish genetics. Aquaculture 255: 1-29.

Excoffier L., Smouse P.E. \& Quattro J.M. 1992: Analysis of molecular variance inferred from metric distances among DNA haplotypes: application to human mitochondrial DNA restriction data. Genetics 131: 479-491.

Faugeron S., Martinez E.A., Correa J.A., Cardenas L., Destombe C. \& Valero M. 2004: Reduced genetic diversity and increased population differentiation in peripheral and overharvested populations of Gigartina skottsbergii (Rhodophyta, Gigartinales) in southern Chile. J. Phycol. 40: 454-462.
FAuvelot C. 2005: Isolation and characterization of microsatellites in two tropical butterflies, Drupadia theda and Arhopala epimuta (Lepidoptera: Lycaenidae). Mol. Ecol. Notes 5: 724-726.

Figurny-Puchalska E., Gadeberg R.M.E. \& Boomsma J.J. 2000: Comparison of genetic population structure of the large blue butterflies Maculinea nausithous and M. teleius. Biodiv. Conserv. 9: 419-432.

Franck P., Guérin F., Loiseau A. \& Sauphanor B. 2005: Isolation and characterization of microsatellite loci in the codling moth Cydia pomonella L. (Lepidoptera, Tortricidae). Mol. Ecol. Notes 5: 99-102.

Frankham R., Ballou J.D. \& Briscoe D.A. 2003: Introduction to Conservation Genetics. Cambridge University Press, Cambridge, $617 \mathrm{pp}$.

Fric Z., Wahlberg N., Pech P. \& Zrzavý J. 2007: Phylogeny and classification of the Phengaris-Maculinea clade (Lepidoptera: Lycaenidae): total evidence and phylogenetic species concepts. Syst. Entomol. 32: 558-567.

GADEBERG R.M.E. \& Boomsma J.J. 1997: Genetic population structure of the large blue butterfly Maculinea alcon in Denmark. J. Insect Cons. 1: 99-111.

Galbusera P., van Dongen S. \& Matthysen E. 2000: Crossspecies amplification of microsatellite primers in passerine birds. Conserv. Genet. 1: 163-168.

Goudet J. 2001: FSTAT V2.9.3, a Program to Estimate and Test Gene Diversities and Fixation Indices. http://www.unil.ch/ izea/softwares/fstat.htlm.

Harr B., Zangerl B., Brem G. \& Schlötterer C.1998: Conservation of locus-specific microsatellite variability across species: a comparison of two Drosophila sibling species, D. melanogaster and D. simulans. Mol. Biol. Evol. 15: 176-184.

Hutter C.M., Schug M.D. \& Aquadro C.F. 1998: Microsatellite variation in Drosophila melanogaster and Drosophila simulans: a reciprocal test of the ascertainment bias hypothesis. Mol. Biol. Evol. 15: 1620-1636.

JARne P. \& Lagoda P.J.L. 1996: Microsatellites, from molecules to populations and back. Trends Ecol. Evol. 11: 424-429.

Keyghobadi N., Roland J. \& Strobeck C. 2005: Genetic differentiation and gene flow among populations of the alpine butterfly, Parnassius smintheus, vary with landscape connectivity. Mol. Ecol. 14: 1897-1909.

Koskinen M.T., Hirvonen H., Landry P-A. \& Primmer C.R. 2004: The benefits of increasing the number of microsatellites utilized in genetic population studies: an empirical perspective from analyses of grayling (Thymallus thymallus) evolutionary relationships. Hereditas 141: 61-67.

Luna C., Bonizzoni M., Cheng Q., Robinson A.S., Aksoy S. \& ZheNG L. 2001: Microsatellite polymorphism in tsetse flies (Diptera: Glossinidae). J. Med. Entomol. 38: 376-381.

MavÁrez J. \& GonzÁlez M. 2006: A set of microsatellite markers for Heliconius melpomene and closely related species. Mol. Ecol. Notes 6: 20-23.

Meglécz E., Petenian F., Danchin E., D'Acier A.C., Rasplus J.Y. \& FAURE E. 2004: High similarity between flanking regions of different microsatellites detected within each of two species of Lepidoptera: Parnassius apollo and Euphydryas aurinia. Mol. Ecol. 13: 1693-1700.

Meglécz E., Anderson S.J., Bourguet D., Butcher R., Caldas A., Cassel-Lundhagen A., D’Acier A.C., Dawson D.A., Faure N., Fauvelot C., Franck P., Harper G., Keyghobadi N., Kluetsch C., Muthulakshmi M., Nagaraju J., Patt A., Péténian F., Silvain J.F. \& Wilcock H.R. 2007: Microsatellite flanking region similarities among different loci within insect species. Insect. Mol. Biol. 16: 175-185. 
Morin P.A., Mahboubi P., Wedel S. \& Rogers J. 1998: Rapid screening and comparison of human microsatellite markers in baboons: allele size is conserved, but allele number is not. Genomics 53: 12-20.

Nash D.R., Als T.D., Maile R., Jones G.R. \& Boomsma J.J. 2008: A mosaic of chemical coevolution in a large blue butterfly. Science 319: 88-90.

NeI M. \& Roychoudhury A.K. 1974: Sampling variances of heterozygosity and genetic distance. Genetics 76: 379-390.

NÈve G. \& Meglécz E. 2000: Microsatellite frequencies in different taxa. Trends Ecol. Evol. 15: 376-377.

Nowicki P., Witek M., Skórka P., Settele J. \& Woyciechowski M. 2005: Population ecology of the endangered butterflies Maculinea teleius and M. nausithous, and its implications for conservation. Popul. Ecol. 47: 193-202.

Paekal R. \& Smouse P.E. 2001: GenAlEx V5: Genetic Analysis in Excel. Population genetic software for teaching and research. http://www.anu.ed.au/BoZo/GenAlEx/.

Pecsenye K., Bereczki J., Tihanyi B., Toth A., Peregovits L. \& VARGA Z. 2007: Genetic differentiation among the Maculinea species (Lepidoptera: Lycaenidae) in eastern Central Europe. Biol. J. Linn. Soc. 91: 11-21.

Pech P., Fric Z., KonvičKa M. \& Zrzavý J. 2004: Phylogeny of Maculinea blues (Lepidoptera: Lycaenidae) based on morphological and ecological characters: evolution of parasitic myrmecophily. Cladistics 20: 362-375.

Pedersen A.A. \& LoeschCKe V. 2001: Conservation genetics of peripheral populations of the mygalomorph spider Atypus affinis (Atypidae) in northern Europe. Mol. Ecol. 10: 1133-1142.

Primmer C.R., Møller A.P. \& Ellegren H. 1996: A wide-range survey of cross-species microsatellite amplification in birds. Mol. Ecol. 5: 365-378.

Primmer C.R., Painter J.N., Koskinen M.T., Palo J.U. \& MERILÄ J. 2005: Factors affecting avian cross-microsatellite amplification. J. Avian Biol. 36: 348-360.

Pritchard J.K., Stephens M., Donnelly P. 2000: Inference of population structure using multilocus genotype data. Genetics 155: 945-959.

Rossiter S.J., Jones G., Ransome R.D. \& Barratt E.M. 2000: Genetic variation and population structure in the endangered greater horseshoe bat Rhinolophus ferrumequinum. Mol. Ecol. 9: 1131-1135.

Rubinsztein D.C., Amos W., Leggo J., Goodburn S., Jain S., Li S.H., Margolis R.L., Ross C.A. \& Ferguson-Smith M.A. 1995: Microsatellite evolution - evidence for directionality and variation in rate between species. Nat. Genet. 10: 337-343.

Rutkowski R., Mazgajski T.D. \& Rejt Ł. 2006: Cross-species amplification of microsatellite loci in European woodpeckers (Picidae). Ann. Zool. 56: 819-826.

Rutkowski R., Olejniczak I., Boniecki P., Tereba A., Cybulska M. \& PARYs A. 2007: Cross-species amplification of microsatellite loci in Orchesella flavescens (Apterygota: Collembola). Genus (Suppl.) 14: 59-62.

SChNeIder S.D., RoEssli D. \& EXCOFfIER L. 2000: Arlequin ver. 2000: A Software for Population Genetics Data Analysis. Genetics and Biometry Laboratory, University of Geneva, Switzerland.

SCRIBNer K.T. \& Pearce J.M. 2000: Microsatellites: evolutionary and methodological background and empirical applications at individual, population and phylogenetic level. In Baker A. (ed.): Molecular Methods in Ecology, Blackwell Science, London, pp. 235-271.
Selkoe K.A. \& Toonen R.J. 2006: Microsatellites for ecologists: a practical guide to using and evaluating microsatellite markers. Ecol. Lett. 9: 615-629.

Settele J., Kühn E. \& Thomas J.A. 2005: Studies on the Ecology and Conservation of Butterflies in Europe. Vol. 2: Species Ecology along a European Gradient: Maculinea Butterflies as a Model. Pensoft Publishers, Sofia-Moscow, 289 pp.

Sielezniew M. \& DzIEKaŃSKa I. 2009: Butterfly-ant relationships: Host ant specificity of Phengaris 'rebeli' Hirschke (Lepidoptera: Lycaenidae) in Pieniny Mts (southern Poland). Pol. J. Ecol. 57: 403-409.

Sielezniew M. \& Stankiewicz A.M. 2007: Differences in the development of the closely related myrmecophilous butterflies Maculinea alcon and M. rebeli (Lepidoptera: Lycaenidae). Eur. J. Entomol. 104: 433-444.

SielezniEw M. \& StanKIEwicZ A.M. 2008: Myrmica sabuleti (Hymenoptera: Formicidae) not necessary for the survival of the population of Phengaris (Maculinea) arion (Lepidoptera: Lycaenidae) in eastern Poland: lower host-ant specificity or evidence for geographical variation of an endangered social parasite? Eur. J. Entomol. 105: 637-641.

Sielezniew M., Buszko J. \& Stankiewicz A.M. 2005: Maculinea arion in Poland: distribution, ecology and prospects of conservation. In Settele J., Kühn E. \& Thomas J.A. (eds): Studies on the Ecology and Conservation of Butterflies in Europe. Vol. 2: Species Ecology along a European Gradient: Maculinea Butterflies as a Model. Pensoft Publishers, Sofia-Moscow, pp. 231-233.

SigaArd P., Pertoldi C., Madsen A.B, Søgatrd B. \& LoEschCKe V. 2008: Patterns of genetic variation in isolated Danish populations of the endangered butterfly Euphydryas aurinia. Biol. J. Linn. Soc. 95: 677-687.

Steiner F., Sielezniew M., Schlick-Steiner B.C., Höttinger H., Stankiewicz A. \& Górnicki A. 2003: Host specificity revisited: New data on Myrmica host ants of the lycaenid butterfly Maculinea rebeli. J. Insect Cons. 7: 1-6.

Tartally A., Nash D.R., Lengyel S. \& Varga Z. 2008: Patterns of host ant use by sympatric populations of Maculinea alcon and M. 'rebeli' in the Carpathian Basin. Insect Soc. 55: 370-381.

Thomas J.A. 1995: The ecology and conservation of Maculinea arion and other European species of large blue butterfly. In Pullin A.S. (ed.): Ecology and Conservation of Butterflies. Chapman \& Hall, London, pp. 180-197.

Thomas J.A. \& Elmes G.W. 1998: Higher productivity at the cost of increased host-specificity when Maculinea butterfly larvae exploit ant colonies through trophallaxis rather than by predation. Ecol. Entomol. 23: 457-464.

Thomas J.A. \& Settele J. 2004: Butterfly mimics of ants. Nature 432: 283-284.

Thomas J.A., Elmes G.W., Wardlaw J.C. \& Woyciechowski M. 1989: Host specificity among Maculinea butterflies in Myrmica ant nests. Oecologia 79: 425-457.

Van Oosterhout C., Hutchinson W.F., Wills D.P. \& Shipley P. 2004: Micro-checker: software for identifying and correcting genotyping errors in microsatellite data. Mol. Ecol. Notes 4: 535-538.

VAn SwaAy C. \& Warren M. 1999: Red Data Book of European Butterflies (Rhopalocera). Council of Europe Publishing, Strasbourg, 260 pp.

Van't Hof A.E., Brakefield P.M., Saccheri I.J. \& ZwaAn B.J. 2007: Evolutionary dynamics of multilocus microsatellite arrangements in the genome of the butterfly Bicyclus anynana, with implications for other Lepidoptera. Heredity 98: $320-328$. 
Weir B.S. \& Cockerham C.C. 1984: Estimating F-statistics for the analysis of population structure. Evolution 38: 1358-1370.

ZaKharov E.V. \& Hellmann J.J. 2008: Genetic differentiation across a latitudinal gradient in two co-occurring butterfly species: revealing population differences in a context of climate change. Mol. Ecol. 17: 189-208.

Zakharov E.V., Hellmann J.J. \& Romero-Severson J. 2007: Microsatellite loci in the Propertius duskywing, Erynnis prop- ertius (Lepidoptera: Hesperiidae), and related species. Mol. Ecol. Notes 7: 266-268.

Zeisset I., Als T.D., Settele J. \& Boomsma J.J. 2005: Microsatellite markers for the large blue butterflies Maculinea nausithous and Maculinea alcon (Lepidoptera: Lycaenidae) and their amplification in other Maculinea species. Mol. Ecol. Notes 5: 165-168.

ZHANG D.-X. 2004: Lepidopteran microsatellite DNA: redundant but promising. Trends Ecol. Evol. 19: 507-509.

Received March 9, 2009; revised and accepted June 17, 2009 